\title{
Exploring Essentials for Keeping the Peace
}

\author{
Osagioduwa Eweka \\ Peace and Conflict Studies Programme, Institute of African Studies, University of Ibadan, Ibadan, Nigeria \\ Email: hoxprince@gmail.com
}

Received 25 October 2015; accepted 3 January 2016; published 6 January 2016

Copyright @ 2016 by authors and Scientific Research Publishing Inc.

This work is licensed under the Creative Commons Attribution International License (CC BY).

http://creativecommons.org/licenses/by/4.0/

(c) (i) Open Access

\begin{abstract}
In theory, three convenient approaches often applied to keep the peace are discernible in international relations. They are Military Power, Democracy, and Free Market. While the former is championed by realists, the latter two are postulated by political and economic liberalists, respectively. However, in practice, there is yet to be a consensus as to which of the approaches is the most practical. This study, thus, with the belief that descriptive accuracy is at the cost of analytical utility-and vice versa-utilises both descriptive and analytical methods to explore the essence of the trio in keeping the peace. The study, while hinging on the theories of realism and liberalism, concludes that Free Market, in spite of its limits, is most essential in the business, considering its productiveness and concreteness. Data for this study are sourced from extant literature.
\end{abstract}

\section{Keywords}

Peace, Conflict, Military Power, Democracy, Free Market

\section{Introduction}

Without controversy, war has been part and parcel of humanity as far back as when humans decided to cohabit. No wonder some scholars have argued that war is a natural phenomenon (Malthus). Two thousand and fourteen marked a centenary of the outbreak of World War I. The century witnessed some of the most devastating wars in history. History records that until then, wars were known for their bipolarity and meagre alliances, as they had often involved not more than two conflicting empires, kingdoms, or countries. Afterwards, wars increasingly became multipolar, involving nearly all the countries of the world as evident in the alliance structure of World War II and its aftermath. This development was undoubtedly accompanied by even harsher devastations than existed in the pre-World War era.

As these devastations began to assume irrecoverable and unbearable dimensions such as unimaginable stagnation leading to gross underdevelopment, there arose an insatiable quest for peace. This search for world peace gradually turned out to be a holistic affair involving presidents, diplomats, war lords, religious leaders, economic experts, scientists and scholars alike. Consequent upon this was the theoretical rhetoric about which among the 
evolving, proliferated concepts, ideologies or approaches could best be adopted to ensure world peace. What are these approaches? What does each of these approaches entail? How is keeping the peace achievable through these approaches? What are the limits of these approaches? Are these approaches effective for keeping the peace according to international best practices? Are there alternatives to these approaches? After attempting these questions using qualitative data sourced from the literature, this study shall determine which approach is most essential in keeping the peace, and why this is so.

\section{Conceptual Pedestal}

Certain basic concepts germane to this study must be clarified for the study to be unmistakably understood. They include Peace, Military Power, Democracy and Free Market. The first task of this section of the study is to clarify the concept of peace. There is certainly no one-size-fits-all definition for the term "peace". The definitions of the term are as proliferated as scholars who have attempted them. Peace, therefore, as a relative concept, is contextually defined and understood in line with specificity of situation. In the most basic concept, peace is the absence of war. Captivating as this definition may seem, it is incapable of capturing the vast dynamics of the subject-matter and therefore hinders the clear understanding of the term-and process. After all, war is but one form of violence (Galtung, 1990). This implies that war and peace can cohabit even within a society. Such a situation is exemplified in Ki-Zerbo's (1978: p. 425) observation on European colonialism in Africa. He observes that there was peace in Africa during colonisation, but it was the European kind of peace. Yet, the dynamics and degree of violence that this European peace brought into Africa was far more ruinous than the wars that the Africans waged against one another. In order to understand the broad, multidimensional concept of peace, Ibeanu (2012: p. 3) deconstructs its definition into three main structures namely philosophical, sociological and political definitions. This he does according to functionality and context. As a matter of relevance, this section of the study will discursively span philosophical and sociological definitions of peace.

The philosophical definitions of peace are those proposed by philosophers such as St. Augustine of Hippo, Jean Jacques Rousseau, Thomas Hobbes and Plato. In the understanding of St Augustine of Hippo, peace is that atmospheric situation existing in one of two identified cities, the City of God (celestial), as against that of the other which he refers to as the city of man which he refers to as corporal (Sabine \& Thorson, 1973: pp. 183-190). Whereas the celestial city is serene and typified by joy and unending happiness, the corporal one is characterized by possessive instincts and additionally riddled with rivalry. On his part, Rousseau's concept of peace is connected with a "state of nature" where man is bereft of aspirations of any kind. In this state, man is naturally good, that is, he exists as a liberal, tender entity (ibid, 533-537). Dissimilarly, Hobbes disputatiously opines that though there indeed exists the "state of nature" that Rousseau talked about, it was not without its conflict-ridden vicissitudes. What he refers to as peace, therefore, is the resultant order (liness) of a social contract created by man, in which all right to self-defence is given-up to a central authority to which everyone in the society is liege.

From the foregoing, it is clear that peace, from the philosophical point of view, is the original condition of the existence of man as orchestrated by the creator $a b$ initio. Invariably, one common thread that runs through all the philosophical definitions featured up to this point is that peace is the faultless, pre-corruption circumstances of man prior to the era of possession, greed and selfishness. Nevertheless, it is instructive to note that this philosophical presumptive standpoint of peace is unfeasible to the contemporary reality of human who has evolutionally crossed the Rubicon of his initial God-given state of existence. In other words, the philosophical definition of peace is more about what ought to be rather than what precisely is. The question here is, what is peace beyond the original inclinations and cravings of human having now found himself in an irreversible social milieu? Plato, in his Republic, attempts to answer this question. One of the first political philosophers, Plato relates peace to justice by averring that the latter is the essence of peaceful existence in society. In a sense, he further defines justice in its simplest term as societal distributive equilibrium, contending that it is a prerequisite for guaranteeing the three functions required to attain harmony in society. These functions include production, security and political rule. For the purpose of this study, production here is conceptually intertwined with free market and security is conceptualised as military power while political rule as democracy. According to Ibeanu (2012: p. 5), justice is compromised where these functions are altered, thus, "in such a context, there cannot be peace and social harmony".

Interestingly, there is a tremendous degree of interconnectedness between Plato's philosophical definition of peace and its sociological counterpart of elsewhere. This link is observable where peace sociologically denotes a situation of social harmony with little or no antipathy. Put differently, peace is sociologically defined as "a con- 
dition in which there is no social conflict and individuals and groups are able to meet their needs and expectations”. Instructively, keeping the peace, as it differs from peacekeeping, implies maintaining this established condition or system and preventing it from collapse. It goes without saying that this is possibly achievable in a society where the people fully take part in government; where produced goods are internationally traded without political hindrances; and where security is provided especially against external aggression, particularly through military power.

The concept of military power in itself cannot be well understood except the term "military" is first clarified. Military represents a group of trained persons authorised and equipped to employ deadly weaponry in support and/or defence of the interests of a nation-state and its citizenry. The primary preoccupation of the military is to defend its territory from external aggression of any form and at any instance. By extension, its task may include but not limited to waging war against another State in line with the laws of (just) war. Extensively, the term captures command, personnel, training, intelligence, science, logistics, armoury, operations, performance, technology, base of operation, number of division, readiness, deployment and morale, to make up a decisively defensive system operational not only in the atmosphere and lithosphere, but also in other sectors of the biosphere. According to Graham (2014), the availability and capacity to use all these elements or threat of same to influence other states represents military power. Following this definition, military power cannot be said to exist when these mentioned elements are in place but are inoperative. To this end, the military power of a state is not evaluated by the availability of these elements but by the capacity of the state to effectively put them to use as and when necessary. For Crocker (2007, p. 12), one of the most necessity-igniting occasions for effective use of military power is in managing conflict in order to maintain global balances and dealing with regimes that refuse to abide by international systems. Art (1980: p. 5) identifies four means through which military power could be put to use: defence, deterrence, compellence, and swaggering. These four means will be subsequently discussed in this study. Meanwhile, it is noteworthy to point out that military power is never static. It may rise or decline depending on the socio-economic and political stability of a nation. Many postulate the unfounded assumption that military power rises where military regime is instituted, and contrastively, that it declines where (liberal) democracy is in practice. Since this study focuses on world peace, it is expedient to equally contextualise military power within an international scope. The concept of military power within the international space does not necessarily differ from the arrangement of individual state in terms of objectives, organisation, weaponry, effectiveness, deployment, employment and institutionalisation. Similar to the structure of the military of a state, the military of the international community is answerable to and defends the interest of the international community such as the United Nations, and is regulated, particularly by the UN Security Council. The major digression of military power at the international level from the national level is that the militaries of several member countries of the UN are what constitute the military power of the international community.

Democracy was practiced for the first time in Greek city-states during the classical period (Danjibo, 2012: p. 303). However, it is a truism that modern democracy is traceable to the United States of America. It later spread across to other parts of the world as an ideology with the help of the Cold War, and was presented by its promoters as the best form of government (Omobowale, 2008: p. 282; Akinwale, 2011: p. 73; Egbuta, 2011: p. 350). With time, it was used as a criterion to form military and economic alliances, thereby compelling developing countries particularly in Asia and Africa to subscribe to it (Akinyemi, 1993: p. 41; Amuwo, 1992: p. 3). Democracy was first defined by Daniel Webster as "people's government, made for the people, made by the people, and answerable to the people" (Lijphart 1999). Thirty-three years later, the President of the United States, Abraham Lincoln, reformed this definition as "government of the people, by the people and for the people" (Igbokwe-Ibeto \& Akhakpe, 2012: p. 238; Adedayo, 2011: p. 26; Egbuta, 2011: p. 350). Since these inceptive definitions, several other definitions have emerged according to different contexts, actors and scholars working towards standardising and establishing it the world over. Thus, the concept of democracy is contested and equivocal given that it means different things to different people and in different situational contexts (Carr et al., 1966; Akinwale, 2011: p. 73). For Egbuta (2011: p. 350), democracy means free and equal representation of people, that is, free and equal right of every citizen/person to participate in a system of government. This is often practiced by electing representatives of the people by the majority of people. On his own part, Onyeoziri (2000: p. 309) presents Bibbio’s definition of democracy as:

[...] a cluster of rules permitting the broadest and surest direct and indirect participation of majority of citizens in political decisions that is, in decision affecting the whole collectively. 
The suggestion of this definition, and, of course, all the other definitions featured thus far, is that democracy is people oriented and as such, it must reflect the common good of the people. In the same vein, all decisions of societal interest must be made collectively by the people and finally, the interest of the people must be held at heart in a democratic setting. Additionally, it involves direct and indirect participation of all citizens in society. In recognition of this fact, Adedayo (2011: p. 31) deconstructs democracy into direct, indirect, constitutional, participatory, consensus, consociation, representative and liberal mutual types. The fact that all the types of democracy are mutually inclusive explains why it is seen as a system (Danjibo, 2012: p. 303). Democracy in this study is thus akin to liberal democracy. In other words, liberalism intertwining with democracy as earlier defined. The idea of liberalism, when interwoven with democracy, introduces certain factors into democracy and makes it metamorphose into a whole new concept of rule of law (constitution) as limits towards the exercise of political power; political pluralism instead of democratic autocratic rule. Viewed from the angle of stakeholders, democracy involves full political contest for power. The cord that binds all these factors together to hold firm liberal democracy is that the elements therein favour balance of power which is absent in an autocratic or authoritarian regime. Therefore, democracy can simply be put as popular participation amidst the above elements.

Away from democracy, free market, also known as open market or free trade, is a condition "where buyers and sellers can make the deals they wish to make without any interference, except by forces of demand and supply”. In clearer terms, it depicts a market system which permits traders (buyers and sellers) to transact freely on the basis of agreement without any form of barrier to market entry in terms of taxes, subsidies and movement of goods, from a government. The freedom or openness involved makes it supportive of competition and "private ownership of productive enterprises” irrespective of race, nationality and religious affiliation. The concept of free market is traceable to the renowned economist, Adam Smith, to whom the theory of economic liberalism is often credited. While it has been contested that Smith did not originate the concept, it is yet to be disproved that he at least popularised it and refined its international dimensions (Smith, 2013). The concept of free market later developed into an international apparatus for keeping the peace and preventing interstate wars. The disparity between the views of economists and laypersons as far as trade is concerned is the leap from individual to national and, by extension, transnational. Factually, the promotion of free trade amongst nations as the best trade policy has been sustained by economists for over two centuries, and so has its scepticism of being an abstract argument advanced by renowned economists who have been repeatedly advised, consequently, that the economy of a nation ought to be protected from foreign competition (Blinder, 2008).

The popularisation of Free Trade by Smith (1776) was borne out of his desire to demonstrate the falsity of the rather extensive set of ideas now called mercantilism, whose doctrine and practice he extensively dealt with in his two-volume Wealth of Nations published in 1776. Mercantilism had argued that government regulation of foreign trade is necessary in order for a country to have "balance of trade", that is, exports greater than imports. To contradict this argument, Smith argues for unregulated foreign trade while reasoning that if two countries can produce two different goods at a lower rate than one another, then it is beneficial for both to exchange these goods with each country trading the good it produces at lower costs for the good it produces at higher costs. This, in economic parlance, connotes absolute advantage. Smith believes that the outcome of this is increasing returns and decreasing labour costs of both countries and further argues that a nation's wealth is "a flow of goods". As he holds, the proper governmental policy towards international trade should be the same as that towards domestic trade; that is, allowing voluntary exchange take place in free, unregulated markets. As it were, Smith believes that this policy of laissez-faire which aims at minimising the role of government intervention and taxation in the free markets would lead to ever higher levels of well-being in all countries as all records gains at the end of the day. The Smithian course of free trade was later charted within a neoteric facet in the nineteenth century by the movement called the Manchester Liberals, championed by Richard Cobden and John Bright, which propagated free economy without any state control and with a total disregard for the social question (Doering, 2004).

\section{Theoretical Construct}

Two theories underpin this study. They are realism and liberalism. One of the most important and recognised theories in international relations, realism, saw the light of day in the twentieth century with Niebuhr and Morgenthau as its champions. In the 1950s and 1960s, another aspect of realism known as the neorealism was established to handle the scientific part of realism in terms of methods in quantitative research (Brown, 2001). The pedestal assumption of realism is that the state is the basic or key actor in international relations (Behr \& Heath, 
2009). Each state has right to military force. Outside the state, there is but a negligible impact from individual citizens, social groups or international organisations for that matter on keeping the peace even in a situation of freedom of arms possession. As such, realism posits that the world is in a state of anarchy. In other words, it lacks a single government; no central power possessing the coercive capacity to enforce its will as realizable in nation states. This being the case, the possible action with which individual governments are left is unclear; thus the pursuit of security and survival by each state. Therefore, each state has the onus to pursue its security and survival through self-defence. However, there are two sides to this postulation. To start with, offensive realism holds that each nation state wishes to maximize political power; therefore, with the slightest invasion opportunity, each country would not hesitate. On the other hand, defensive realism holds that the issue is not about maximizing political power but about defending one's interest or one's territory, and this is the key element in defining the actions of individual governments. Whatever side is more realistic, the fact remains that the consequences of maximisation is more often than not balance of power and deterrence. If it is assumed that military capability is best for peace or for prevention/stoppage of aggression and warfare, then balance of power is indispensible to deter other military might from excessive warfare.

Antithetically, liberalism is located as the opposite of realism. Yet, liberalism takes civil society as basic actor in international relations. This may sound strange as the right to decide foreign policy is reserved to the government and anything is justified by reason of state (Bull, 1995). However, taking the assumption that each government depends on the will of the public, and that each government is responsible to the civil society from which they are elected, then the state becomes a neutral institution which simply reflects the will of the civil society (Moravcsic, 1992).

Borne, in the 1970s, out of the complex interdependence of states, particularly since the end of the Cold war, liberalism is of three variants. Political liberalism focuses on the form of governance in each country. Here, the spread of democratic government, that is, governments that are responsible to the people would be critical in the promotion of peace in the world. The second variant would be what is called the economic liberalism which focuses more on the market structure than political structure. The promotion of free trade and open market would make each nation more dependent on each other, and with this increase of interdependence there would be a decrease in likelihood of war. Additionally, this would astronomically skyrocket the cost of war. So, free trade is regarded as a deterrent against militant behaviour and war. The third variant is liberal institutionalism which is usually associated with international law and international institution. It postulates that the promotion of international institution building in international relations is critical in maintaining peace. Thus, liberalism favours and recognises the place of internationalism with regard to keeping the peace more than realism. From the foregoing, it is evident that while realism propagates and substantiates military power, liberalism-political and economicpropagates democracy and free market, respectively, as the most reliable form of power and mode of keeping the peace.

\section{When Military Power Keeps the Peace...}

The goals that nation states pursue vary considerably from case to case. This is also true about the international community: events leading to the establishment of the League of Nations soon after World War I to the establishment of the United Nations after World War II have shown that there is a relationship between force and foreign policy in an anarchic environment. These goals range from economic to political; and are achievable through diverse means. One common thread that binds all these goals together is world peace. Military power is more useful for realising some goals than others, although it is generally considered by some states for all of the goals that they hold remarkably on occasions when diplomacy seems or has proven unrewarding. Suffice it to add that the commonest means applied by the international community towards achieving its goal of world peace is military power. According to Crocker (2007), in managing conflict, the use of force as well as military power continue to play a vital role in maintaining global power balance and dealing with regimes that refuse to abide by the international system. Four distinct categories from Art (1989) analytically exhaust the functions that force can serve as being defence, deterrence, compellence and swaggering. While the aim of defence is to ward off attacks or minimise damage if attacked, deterrence is meant to prevent adversary through threat of retaliation targeted at population or industry of the adversary nation. While compellence involves deploying military forces to be able to stop an adversary or get them to do something, swaggering involves show of force, that is, pride of military might. Remarkably, although defence and deterrence are alike in that they serve the common purpose of dissuasion, 
self-protection and protection of others, they can be independent of each other. Similarly, compellence is closely related to deterrence save its relative vagueness. In the same vein, swaggering may serve the purpose of deterrence in a passive way.

As a tool for keeping the peace, military power can possibly be put to use principally in two ways, either: (i) physically-actual deployment against adversary, usually but not always in a mutual exchange of blows-or (ii) peacefully-explicit threat to resort to force, or to the implicit threat to use it that is communicated simply by the party having it available for use. Apparently, whereas "i”" here-above boils down to compellence, "ii" boils down to deterrence.

Compellence

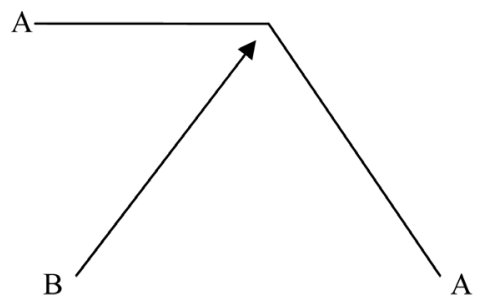

(1) $\mathbf{A}$ is doing something that $\mathbf{B}$ cannot tolerate

(2) $\mathbf{B}$ initiates action against $\mathbf{A}$ in order to get him to stop his intolerable actions

(3) A stops his intolerable actions and $\mathbf{B}$ stops his (or both cease simultaneously)

\section{Deterrence}

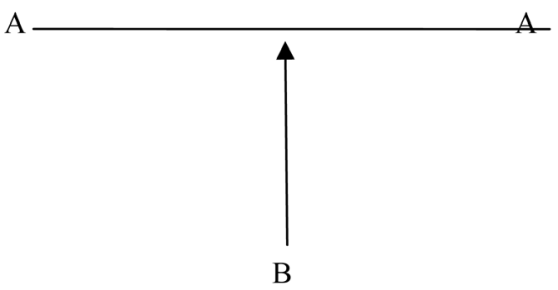

(1) $\mathbf{A}$ is presently not doing anything that $\mathbf{B}$ finds intolerable

(2) B tells A that if $\mathbf{A}$ changes behaviour and does something intolerable, $\mathbf{B}$ will punish $\mathbf{A}$

(3) A continues not to do anything intolerable.

Source: Robert J. Art (1989).

In a situation where $\mathrm{A}$ sends a signal to $\mathrm{B}$ that $\mathrm{A}$ will revenge any act of aggression against $\mathrm{A}$, realists have argued that there will be a slim possibility for B to invade A as B would always have at the back of its mind that there is the possibility and ability for A to truly retaliate as well as the loss and cost of such retaliation. Nevertheless, the first conspicuous scepticism attached to the idea of the use of military in keeping the peace is that of viability and sustainability. It is never sure $a b$ initio that deterrence will work, and if eventually it does, it may be unfeasible to sustain. This scepticism culminates in the difficulty or even inability to verify the claim of realists that deterrence indeed prevents wars even amidst seeming circumstances. For realists, the lack of war is interpreted as successful deterrence while the outbreak of same is analogous to failure of deterrence. While this may be true, what is even truer is that it is a very difficult task to prove the actual success or failure of deterrence strategies through its sheer (expected) outcome.

The limit of military power in keeping the peace cannot be overemphasised. It straddles on two platforms and culminates in failure to prevent wars. The first is aggressiveness of power. Powers that are poised to accept the cost of retaliation are known as aggressive powers, and such powers cannot be deterred. Although this is an extremely rare case in international relations, yet examples abound. A case in hand is that of Germany/Poland under NSDAP (the NAZI regime). Adolf Hitler was ready to start a war in Europe regardless of actions from the British or the French government, and to that effect, the conference of Munich was futile for peacekeeping because, whatever the resolution, Hitler would still have gone on with the war. In the same vein, threats from Britain, France and other nations did not deter him. Rare as this kind of situation may seem in contemporary times, particularly in international relations, it happens to be a gap now filled by terrorists especially since the wake of the twenty-first century. Military power and/or deterrence is bound to fail in keeping the peace in a suicide bombing situation. It is unimaginable to face a suicide bomber and threaten to kill them if they pull the trigger. Of course, the terrorist in question must be sure and ready to die. So, terrorism is one political action that cannot be deterred by mere aggressive action. The second platform on which the limit of military power in keeping the peace straddles is proactive attack. Powers convinced of the ever readiness of attacks from their adversaries cannot be deterred. The logic is that such powers would seek to attack first in order to have the war started on their own terms and, in other cases, in an attempt to disarm their adversaries. When the situation of war is so tight that its pre- 
vention is unfeasible, an aggressive power is dissuadable, thus military power becomes impotent in keeping the peace. The attack on Pearl Harbour (Hawaii), 1941, exemplifies this point. Although Japan was militarily unprepared for a war with the United States of America, which explains their (Japan's) defeat in the war, Japan was very much unmistakably aware that the US might launch an attack against them at any moment. Another more recent instance would be the Sino-Indian border conflict of 1962 which resulted from China's influence on or claim of Tibet. For China, pre-war events presupposed that the war was imminent with Indian forces and as such China launched a proactive attack which they presumed to be strategically advantageous.

In addition to the above, the possibility of accepting status quo may also be a limit of military power in keeping the peace. This is also partitioned into two strap lines notably perceived imminence of attack and attack as last resort. The perceived imminence of attack is exemplified in a case where a nation state, for the paranoia of possible attacks from another, decides to embark on a pre-emptive attack; of course, the action will not be deterred. One remarkable fact about perceived imminence of attack is that the more it is heightened, the less there is a possibility for a successful deterrence. Similarly, when a government sees attack as last resort, there is less possibility for such government to accept status quo, and therefore, deterrence might breakdown. The aforesaid are arguably attributable to two basic factors being vague warning signs and mingling of warning signs. Where warning signs sent by a deterring party are unclear or practically vague rather than precise, comprehensible and decisive, the proposed action is bound to be likewise unclear, and as such, the adversary may interpret it as a mere threat or sheer lack of capacity of the deterring party to carry-out the threat of retaliation. Similarly, mingling signs have to do with the deterring party presenting more than one threat to the adversary, thus the latter may capitalise on the least aggressive of all the multiple warning signs put forth by the former and launch aggression.

\section{When Democracy Keeps the Peace...}

The first task here is to deliberately relate democracy to international politics or international relations. It may appear rather surprising to link democracy to international politics since it has a lot to do with domestic politics. It suffices to mention, therefore, that this trait is particular to traditional democracy, as modern democracy is largely directly linkable to international politics thanks to the birthing of the international community of democracies which, many have argued, would bring about peace and make the world a safer place. This does not mean that traditional democracy and international politics are completely mutually exclusive given that traditional democracy, in spite of its local or nationalist mannerisms, and having strong influence on domestic society, may also make it have strong implications for foreign policy making at national level. Woodrow Wilson, the 28th president of the United States (1913-1921) was one of the earliest to advance the argument that the emergence of the international community of democracies would assure world peace. While justifying World War I as one war which would make the world a safe place for democracies (countries practicing democracy as a system of government), he argued in favour of three basic views. First, he viewed "democracy" in his time as the United States of America, that is, the security of the United States and of emerging democracies in Europe. However, it may be argued that Wilson's opinion was borne out of his zeal to establish democracy firmly in European continent. Another factor that occasioned his view may have been his willingness to expand democracy in the world (Slaughter, 1995). A consideration of Wilson's participation and contribution to the Paris Peace Conference of 1919 may suggest that he aimed not only at defending the people of democratic nations but also at expanding democratic governance in the world at large. Suffice it to add that this move was what initially brought about interweaving democracy, which is rather a domestic affair, with international affairs. Thenceforth, there was a noticeable combination of democracy as a domestic affair and democracy as an idea and an institution in the global state of affairs.

The (im)possibility for democracy to be a viable approach to keeping the peace is analysable through the notion of democratic peace. The notion that connects democracy to peace comprises two phases, one of which is rather philosophical and credited to Immanuel Kant (1975), the renowned philosopher who argues that three foundations are necessary for peace. These are constitution enacted by republican governments, rather than one dictated by a king or a military ruler; the law of nations founded on a federation of Free States; the law of world citizenship and freedom of emigration, rather than a law between governments. A thorough dissection of these three foundations would reveal a possible contraction into one-the first one. It should be noted that as at the time of Kant's proposition, the world could boast of very few republican governments and constitutional monarchies. Therefore, during that epoch, constitution was an aspirational goal rather than a reality. Now, the foregoing argument may portray republicanism as same as democracy, especially as Kant believes that republicanism is far more peaceful 
than other forms of government. In the adaptable opinion of Kant, republicanism can exist even in a monarchical system of government where a constitution regulates the powers of the monarch. One noticeable fact in the argument of Kant is that he avoids the use of concepts related to democracy such as universal suffrage, but about free makes recourse to those related to Free States and world citizenship. Nevertheless, it appears that the kind of republicanism he talks about is liberal democracy, that is, a form of government where participatory efforts of the people help to keep the power of the regime in check through constitutional means.

One would then wonder to what extent Kant's argument is true that democracy is peaceful, or that it is the best approach to keeping the peace in the world. The Greek philosophers, on the contrary, averred that democracy is a problematic form of government that may result in dictatorship and full blown war, and thus expulsion of peace, in spite of the fact that democracy rests on the assumption that everybody participates in decision making. The argument here is that if allowed freedom, the populace may elect a dictatorial leader, and also, the populace has the tendency of mass mobilization for violent conflict-war. This is not to say that democracy is anti-peace or relatively dangerous and prone to war, but one must not hastily glide into the dogmatic conclusion that it is the best approach to keeping the peace. In fact, it should be noted that the argument favouring liberal or democratic peace was tied to the realities of the (post)World War I era, and may not augur well for the realities of (post)World War II era. This owes to the fact that international politics was basically structured by the relationship between the US and the USSR during this period and for a long time afterwards. To be precise, the bedrock of international politics during this period was principally nuclear deterrence as noticeable in the case of the US and Cuba under Fidel Castro in 1963, among others. Then, at the decline of the Soviet Union marking the end of the Cold War, there was already a firmly established committee of democracies in the world as the US was said to have emerged victorious in the Cold War and as such exerted democracy in so many countries of the world. This brought about the idea of democratic universalism which is about a global body of democracies as opposed to nationalism. This community, it must be mentioned, was devoid of geo-political contestation being that it comprised countries sharing the same ideology_democracy, thereby exemplifying the link between democracy and peace.

On the second phase connecting democracy to peace, Doyle (1983) argues that in the history of the world, nations practicing democracy have never been involved in wars between one another. This is not to say that it is impossible for there to be wars between democracies, rather, his argument was borne out of the results of an empirical study which he carried out. In his essay, he points out there views: First, he thinks Kant may have been right to state that there may be the impossibility for democratic nations to fight each other. Second, if they had their way, democratic nations would prefer their adversaries to be authoritarian regimes or nations rather than fellow democratic nations. The meaning of this is that if democratic nations do not embark on wars with their counterparts, it is more of a decision or a deliberately designed reward from the community of democracies for countries that have chosen to tread the path of democracy and not a mere coincidence. Third, wars fought by democracies are not democratic or peaceful. This last point infers that democracies, if they must engage in wars with autocratic regimes, indulge in offensive rather than defensive wars. In other words, what democracies actually fight against is not the nation, not the people nor the government of their adversaries, but the system of government-autocracy. The argument, here, is therefore not that democracies are absolutely peaceful, not that they do not fight wars, but that they prefer to channel their weaponry and combative energy towards authoritarian regimes and not towards their counterparts. Be that as it may, war is war, whether fought among democracies or between democracies and autocracies.

Since the end of the Cold War, the idea that the expansion of democracy may guarantee more peace in the world has been in the fore front of peace scholarship in some quarters and two notable hypotheses have been popularised as hermeneutics for peace, that is avoidance of war, among democracies. They include the institutional hypothesis which attributes democratic peace to the reality that political decision in a democratic dispensation are restrained or censored by representative institutions, a situation which allows for moderation of high risk decisions. This hermeneutic would come to be eroded by the normative hermeneutic which postulates that democratic governments cannot be receptive to wars from their counterparts given that they have values and political institutions in common. Having established the absence of war among nations stably practicing democracy, what Doyle failed to establish is whether democracy is actually the reason for such absence.

The end of World War II saw militarism and military regime in Germany and Japan dismantled. With this, one may be quick to think that the foundation of peace was laid as these two nations were hitherto major military powers. Also, this period was characterised by the spread of democracy not only in Germany and Japan, but to other European, African and southern Asian nations as well. Thus, there was bound to be the belief that the pos- 
sibility of warfare had been reduced. This was definitely not the case. Many wars have been led by democratic governments since the end of World War II. The fact in the issue is that engaging in wars has little or nothing to do with regime being democratic or otherwise for, the military, unlike the opinion of champions of democracy, does not necessarily always support wars. In fact, there have been instances where the military in a democratic dispensation has been reluctant in supporting warfare even when civilians called for it especially as they had no means of (re)acting against the decision of parliament. This therefore counters the argument that civilians are more peaceful than the military. A good example is the Falklands War of 1982 between Britain (under Thatcher) and Argentina. Another handy example is the Gulf War. When Iraq evaded Kuwait under the Hussein regime and the international community was expected to react militarily, Colin Powell, the then Chief of Army Staff of the US expressed his reluctance to retaliate and bail out Kuwait from the invasion of Iraq, but president Bush went ahead to declare war on Iraq and was eventually successful. A similar example is the war on Iraq in 2003 which was supported by the people and the congress as a battle in the then on-going war on terror. The aim of the war was to make Iraq one of the countries on-which democracy was being imposed. This turned out eventually to be one of the longest military engagements in the history of the world.

So far, the arguments for and against as well as the lacunae in democracy as an approach to keeping the peace can safely be said to be inane of laboriousness. It should however be added that the number of people participating in politics in a democratic milieu might open-up a possibility for a dictatorship or even a war especially when the public is untrustworthy. The argument of Kant and his disciples who validate democracy as the best approach to keeping the peace rests on the belief that the people are more rational when it comes to war, unlike kings or dictators who may have little or nothing to fear in case of an outbreak of war. However, there is a fine line between transition to democracy and stability of same mostly in a situation of ethnicity. Transition to democracy may actually result in turmoil rather than calm. While it is true that the transition to democracy might engender more credible governance that can increase the possibility of peace, the usually lengthy, unstable period of democracy comes with the disturbances of ethnic and religious incongruences in defining the nation's policy. In recent decades, many nation-states in the Western hemisphere have experienced transitions from authoritarianism to democracy. Yet, such shifts have not meant that the resulting political systems are just or sustainable. Rather, nascent democracies continue to be plagued by the precarious rule of law, widespread corruption, and failures to protect civil liberties. These issues have led analysts to label such democracies "liquid" or "delegative" (Litvinenko, 2012; Sznajder \& Roniger, 2004). This is obvious in countries like Libya, Egypt and Iraq in the initial stage after revolution and soon after the overthrow of dictatorship. In most cases, it may be a mirage to believe that a change of authoritarian regime will make the people welcome democracy. In a situation where there is a change of regime, usually forceful, and the people eventually refuse to welcome democracy; the end result is usually devastatingly violent. In which case, democracy is said to be counterproductive. In most cases, forceful imposition of democracy on the people is usually responsible for its rejection even after an authoritarian regime has been gladly sacked. A case in hand is the Iraqi situation where the principally Muslim populace, after the fall of the Hussein regime, refused to welcome America and its ideologies as a result of the perceived sinister motive and double standards of America. One should not also be quick to ignore the paradox in the act of engaging in long lasting wars in order to enforce a system of government considered as a tool for keeping the peace.

Although Doyle has been able to historically prove that stable democracies have never had to fight war among themselves, he failed to factor in unstable democracies as did Bruce Russet. After all, it cannot be said that all democracies in the world are stable. Factually speaking, for a very long time, unstable democracies have continued to be viable warfronts as played out in Weimar Germany among others which, by virtue of being unstable democracies, first turned into authoritarian regimes before the outbreak of war. It is a paradox that Weimar Germany was one of the most democratic nations prior to World War I but crumbled at the end of the war sequel to the Nazi take-over. Another case in point was Japan which was largely a liberal regime, which, although excluded women from its suffrage, was in several ways analogous to a democracy particularly in the 1920s. But until the rise of totalitarianism and of militarism, the country was engaged in an almost irrecoverable war. Russia and Ukraine would pass for another example although Ukraine is oscillating between stability and instability of democracy. Thus, it is clear that the breakdown of unstable democracy precedes the outbreak of war.

\section{When Free Market Keeps the Peace...}

The significance of free market to keeping the peace is glaring in the cases of post-World War II Europe, con- 
temporary US-China economic relations and US-Russia economic relations. Right from the 18th century, Europe was already ravaged with series of wars: the Franco-Prussian war, the Napoleonic wars, the World War I and II. After World War II, European states converged to discuss measures to prevent the outbreak of another war. It should be noted that none of the treaties signed by European states was as effective for keeping the peace as those of free market.

In March 1951, France and Germany cast away their suspicion and began to expediently discuss integration of economic policies which would result in disregard for national sovereignty as far as economic issues are concerned. This was a giant stride from the traditional hostile Franco-German relationship towards a Franco-German rapprochement. That same year, the Paris Treaty was signed to set up the European Coal and Steel Industry. With the participation of other European countries, it became impossible for either France or Germany to exploit the industry for war production as it was now under the control of “The High Authority”. This later led to the Treaty of Rome in 1957, giving birth to the European Economic Community (also known as the Common Market) and the European Atomic Energy Treaty. In 1960, the European Free Trade Association established by the treaty of Stockholm paved the way to better European economic integration such as the Common Agricultural Policy. In 1967, all bodies came under one umbrella called The European Commission.

The objectives of these agreements were a common tariff; harmonization of tariffs vis- $a$-vis that of foreign and non-member states; to allow for an economically borderless Europe and; ultimately, to ensure the prevention of war and keep peace among European countries. Interestingly, about 80\% of European countries subscribed to this move which economic liberals term "commercial peace” and which brought about relative peace to Europe. Apparently, a country with a reason to wage war against another, viewed as an adversary, would most likely change her mind considering what she has to lose economically. Additionally, now that majority of the countries have given up economic sovereignty and control of coal and steel, it would be impossible for any one of them to single-handedly decide on acquisition of nuclear weapons or other high degree weapons.

Another pointer to the indispensability and viability of free market in keeping peace is its utility by China to establish and foster peace between itself and other nations. In this regard, the General Secretary of the Communist Party of China (CPC) asserts that China loves peace and would follow a path of peaceful development, particularly through its diplomatic policies. As exemplarily delineated in its economic relationship with the United States, China offers that free market is capable of presenting itself as a tool for regulating conflict and infusing peace in order to create an international environment essential to socio-economic development regarded as "complex interdependence”. Relations among the major Western powers fit this model of complex interdependence very well. The United States has significant disagreements with its European and Asian allies over trade and policy, but it is hard to imagine a circumstance in which the United States would use military power against any of these allies particularly as attempts at military power has proved futile in the past. In 1995 when America refused to allow the then Taiwan's president to make a high profile visit to America for diplomatic reasons, China reacted militarily by firing ten unarmed DF-15s into waters off Taiwan. America launched counteractive troops and aircraft-carrier to the region and China quickly backed-off. At this point in time, China was not an economic giant, whereas the US was. In fact, there was a remarkable gap between the US and China in terms of economic abilities. It was probably for this reason that China reached the prudent decision to back off. It is significant to remark that since China assumed its current, acclaimed economic and military status, the US has taken dressing and has not dared to threaten China because, as remarked by Douglas Paal, unofficial American ambassador to Taiwan, the cost of conflict has certainly gone up for America to easily afford. Instead, the United States now relies on economic pressure, negotiations and incentives to achieve its policy aims.

Several scholars, journalists and politicians have reiterated that the bilateral ties between both countries are strengthened by free market in particular and economic alliance in general. It should be noted that there exist quite a number of Chinese entrepreneurs in the US and vice versa. Also worthy of mention is the fact that the free trade existing between the United States and China is on the increase and the economies of both countries are benefiting so immensely from it that they cannot allow a war to bring it to ruin. For instance, the two countries are largely interdependent for production and marketing of an array of technological gadgets. This is what their bi-lateral ties are basically about. This has been inferred in many instances. As Kerry (2014), US Secretary of State avers, "China and the United States represent the greatest economic alliance trading partnership in the history of humankind, and it is only going to grow”. He further asserts that both countries seek to strengthen their security relationship which grows out of the economic relationship at the same time. This undoubtedly implies that bilateral trade and free market between both countries have resulted in a military or security relation- 
ship which discourages armed conflict of any degree and kind. Although Hitchens (2002) argues that no power has been able to match the US economically and militarily as China, recently, the East Asian Strategic Review (Katahara, 2014: p. 20) indicates that current diplomatic policy among both countries is carrying forward the path of peaceful development through free trade, and this is seen as "a new type of major-power relations upon which both countries have formally agreed”. Similarly, Yang Jiechi of China has put forth the argument that "[...] business not only brings goods and jobs to us, but also mutual understanding and friendship among our peoples". In concord, Jacob Lew of the US remarks the "people-to-people" engagement that "goes beyond the business world".

Up to this point, it has been argumentatively and historically ascertained that free market, more than the other identified tools for keeping the peace, has the capacity to uphold relationship between nation states such that peaceful coexistence and collaboration are possible and sustainable, towards the attainment and sustenance of peace among them. This is not to suggest that violent conflict is forcibly inevitable between nation states with the absence of free market relationship or pronounced economic alliance. For instance, the United States has a remarkably insignificant economic alliance with countries such as Brazil, India and Turkey, yet they are not at loggerheads with them. The suggestion here is that such absence or minimization, which is often occasioned and at the same time sustained by rivalry rather than constructive competition, is much likely to make nations prone to violent conflict institutionalization and/or solidification, whereas the reverse is indisputably the case in the presence of free market. In other words, economic competition is peaceably worth more than economic rivalry when it comes to keeping the peace. At this juncture, in order not to be guilty of analytical disequilibrium, it is pertinent to take a critical look at the other side of the coin by giving due consideration to instances where the absence of free market has not only proved itself to be conflictogenic, but also pro-conflict. The United States of America and Russia conveniently fit this description.

The hostile behaviour existing between the US and Russia is not unrelated to their failure to explore free trade with each other. The origins of bilateral trade relations between both countries are traceable to the period antedating the World War II. The peak of these relations dates back to the period between 1941 and 1945, while the period that followed ushered-in the decline of these relations. Since then, the economic relationship between the two powerful nations has been rather remarkably low and intermittently fluctuant. However, it is not as much of significance to this paper to dwell on this issue as it is to discuss the violent conflict effect of the absence of free market between both countries. Russia, by virtue of being a major producer of natural gas and oil, is a vital actor in the international economy being the $4^{\text {th }}$ largest economy in the world since 2013 till date (Russia Insider, 2015). This implies that the country is quite significant to the global economy. In spite of this pedigree, the overall US-Russia economic relations remain significantly weak to the point that both countries account for an impoverish portion of the international economic activities of one another (Nelson, 2014). According to the Global Trade Atlas, corroborated by the Bank for International Settlements and the Bank of Russia, Russia housed less than $0.5 \%$ of the foreign investment of the US as of 2012. In 2013, export of goods from the US to Russia was estimated at only $0.71 \%$ and $1.19 \%$ vice versa. In the same vein, at the end of 2013, Russia had an outstanding US bank loan of $1.1 \%$. Similarly, the US accounted for less than $1 \%$ of the foreign direct investment in Russia at the end of 2012. In all these, the European Union has managed to remain at the favoured end.

The foregoing explains why the two countries have been able to afford enduring, episodic conflicts with one another, with little or no discomfort and hesitation to the extent of periodically arriving at the brink of mutual exchange of nuclear blows specifically by means of threatened proxy wars, latest of which Ukraine and Syria are potential theatres. Both countries seem to directly have nothing economically at stake to make them sheathe their swords. This goes further to explain the nonimpact of economic sanctions and countersanctions periodically imposed by both countries on one another. Noteworthy, these sanctions and countersanctions double as cause and effect of absence and/or weakness of free market between the countries. As Nelson (2014) succinctly posits,

The indicators suggest that the direct effect of US sanctions on Russia on overall trade and investment could be relatively small for the United States and Russia. However, sanctions could disrupt specific economic activities at the firm-and sector-level, improving economic costs on specific US and Russian firms and industries.

It may therefore be argued that if these sanctions have relatively small effect on the United States and Russia, it then continues to widen the gap of peace between them. If this be the case, it would mean that the effect the sanctions would have on the European Union (EU) would be unquantifiable since the EU has also been caught 
imposing sanctions on Russia, as seen for instance in the Russia-Ukraine conflict of 2014, in spite of it being much economically in tandem with Russia, a situation which has continued to play a major role in keeping the peace among both parties, unlike their US counterpart. There is no disputing the fact that the peaceful rapprochement between Russia and the EU countries (significantly Germany) is deeply rooted in free trade. So, the worry here is whether these sanctions would accordingly bring, or why have they not brought, to an end the peaceful rapprochement between Russia and the EU. This may not necessarily be the case.

The technicalities and motives involved in the degree and manner of sanctions imposed on Russia by the EU differ from those of the US. Arguably, the collaboration of the EU with the US to impose sanctions on Russia can be said to be largely politically orchestrated. If the EU had refused to collaborate with the US in this venture, they would have almost completely, irrecoverably fallen out of the age-long, profitable economic alliance with the US, and such a move would have been economically and diplomatically consequential, yet an unreserved collaboration would have equally spelt doom for them on the Russian side. Hence, it is safe to regard the EU, under this peculiar circumstance, as a victim of circumstance as well as of historical vengeance caught in the inescapable web of multilateral cooperation of politically conventional array of sanctions. Therefore, what the EU tactically resorted to, in order not to be economically and diplomatically irrelevant in the eyes of both Russia and the US, was to courteously but stealthily sit on the fence by indulging in selective sanctioning. This is evidently exemplified in the obvious reluctance, difficulty and tardiness displayed by European leaders in reaching a consensus on sanctions on Russia until it became glaringly unavoidable. It is even further and better exemplified in the selectiveness and economic impoverishment of the sanctions which were again fickly implemented, unlike the case of the US which has been found to be rather relatively annihilative and malicious.

In the presidential statement following the 2014 shooting of a civilian airliner transporting citizens of the Netherlands, Malaysia, Australia and other countries by Ukrainian rebels purportedly backed by Russia (The White House, Office of the US President, 2014), Barack Obama affirmed that:

Today, and building on the measures we announced two weeks ago, the United States is imposing new sanctions in key sectors of the Russian economy: energy, arms, and finance. We're blocking the exports of specific goods and technologies to the Russian energy sector. We're expanding our sanctions to more Russian banks and defense companies. And we're formally suspending credit that encourages exports to Russia and financing for Economic projects in Russia (Underlining by author).

The president further affirmed that:

At the same time, the European Union is joining us in imposing major sanctions on Russia [...]. In the financial sector, the EU is cutting off certain financing to the state-owned banks in Russia. In the energy sector, the EU will stop exporting specific goods and technologies to Russia. In the defense sector, the EU is prohibiting new arms imports and exports and is halting the export of sensitive technology to Russia's military users (Underlining by author).

The underlined words and phrases in the above extract of the US president's statement reveal the contrast between the intensity, motive and level of involvement in the imposition of sanctions on Russia by the US and the EU. In the first quote, the underlined words and phrases depict nihilism, malice, rivalry as well as unwillingness of the US to firm-up any economic, bilateral tie with Russia, let alone establish free trade with it. Contrastively, the underlined words in the second extract here-above depict hesitation, indecision, reluctance, prudence and unwillingness of the EU to discontinue economic, bilateral ties and firmly sustain the existing free trade with Russia. In clear terms, it can be safely implied from the foregoing that while the EU may have gotten involved in the sanctions on Russia because of expediency in international politics and conventions, the US may have reeled out its own sanctions for two basic reasons apart from deterrence. First is that it was found economically inconsequential and secondly, the military and politico-economic rivalry unchangingly characterising the relationship between both nations was conspicuously overboard, thus the US considered show of power as expedient if Russia must not grow to become an untameable threat. Same can be said about Russia coming up with its countersanction activities. This standpoint is evident in the following extract from the aforementioned statement of the president of the US:

[...] the sanctions that we've already imposed have made a weak Russian economy even weaker. Foreign investors already are increasingly staying away. Even before our sanctions today, nearly $\$ 100$ billion in 
capital was expected to flee Russia. Russia's energy, financial, and defense sectors are feeling the pain.

Projections for Russian economic growth are down near to zero.

The summative inference extractable from the above is that it is easy and convenient for countries to imprudently engage in a sanction and countersanction parade where both countries do not have much economic leverage over each other and, as such, mutual exchange of sanctions would not necessarily impact economic interests. Otherwise, economic 'pain' would be avoided for being contagious.

Relative to other countries with which the US practices Free Trade, certain factors are responsible for the economic alienation of US-Russian trade culminating in strengthening protracted, intermittent uprisings among themselves. Firstly, the US does not grant Russia permanent normal trade relations (NRT) status. Secondly, Russia is not a member of the World Trade Organisation (WTO) and OECD. Thirdly, there is a lack of a ratified bilateral investment treaty among the two countries (Deutsche Bank Research, 2009). Recognising the import of free trade in keeping the peace, Charap \& Kuchins (2009) postulate that economic ties are important in their own right, but may in addition help to provide the broader bilateral relationship. This postulation buttresses the thesis of this study that deep economic ties in form of free trade, as exemplified in the case of Russia and Germany as well as France and Germany, is highly efficient in bringing about peace through stable political cum diplomatic relationship. The hostile relations evident between Russia and the United States cannot be said to outweigh those of Russia and Germany or France and Germany prior to their decision to sacrifice their hate, malice, jealousy and rivalry on the altar of revolutionary economic collaboration (free trade). If the US and Russia decide to chart this same productive course towards attainment of peace, violent conflict among them and by extension among their numerous allies-is most likely to reduce to its barest minimum, and, judging from the Russia-Germany/France-Germany experience, the feasibility of resurgence appears to be quite slim. If on the contrary they continue to shun the exploration of mutual free market, their hostile relations and alienation of peace would likewise continue to be nurtured.

Nevertheless, there are limits to the concept of free market as a tool for keeping the peace. Two shall be briefly discussed here. First, there may be instances where religious or racial issues may hinder free market. Two clear examples are the experience of the Jews in the 20th century France and Nazi Germany when the Jews were persecuted purportedly for being commercially prosperous. The commonest instance is the case of Alfred Drefus (Affaire Drefus), a Jewish accused of treasonable offences such as espionage and divulging of French government's secret documents to the German government. In the end, the accusation was discovered to be false in its entirety. Given such a situation, there may arise the possibility of retaliation from the government of the accused person, either by devising measures of hindering the commercial activities of the nationals of the accusing country, or simply launching a retaliatory accusation. In either case, the end result may be full-blown armed conflict. Another limit may be that countries may not be willing to go into economic alliance with other countries, either for historical reasons or for reasons of reward divide as played out in the case of Russia and the US after the Cold War.

\section{Conclusion}

Historically, instances abound of the shortcomings and outright failure alike of military power to keep the peace: Iraq, Libya, Afghanistan, etc. In fact, many scholars of war studies have attributed the outbreak of World War II to the failure of military deterrence. Deterrence is a 50-50 chance, and when it fails, one is left with either war or surrender, the outcome of which is most times unbearable devastation. This is why other alternatives at peace must be explored. These alternatives, as analytically demonstrated in this paper, coincide with democratic rule and free trade. Deplorably, democratic rule also shares the ill-fate of military power. It is yet to be proved that peace is attributable to democratic rule. The fact that West European nations do not wage war against one another is unconnected with the unanimous practice of democracy but links to the consensus that the Soviet Union is a larger, lethal and collective threat to their wellbeing than anyone among themselves. The meaning of this is that the case would not have been different had the Soviet Union been a democracy. In other words, war can be said to be a function of lack or availability of common enemies irrespective of any system of government. The reverse being the case, peace is still not guaranteed as war is war between democracies or between democracies and authoritarian regimes. Indeed, contemporary realities suggest that it is politically impossible to democratize the world, yet the quest to achieve this Sisyphean task has driven humanity to some of the most regrettable and longest wars in 
history, more so as democracy is often transported by war itself. Besides, one would wonder the fate of unstable democracies since only stable ones are said to be effective mechanisms for keeping the peace.

For centuries, the implicit or explicit relegation of free trade, as an apparatus for keeping the peace, in favour of its other counterparts offer nothing but unprecedented strife in the international scene. For instance, the $16^{\text {th }}$ and $18^{\text {th }}$ centuries were recognised as a period when Western nations pursued mercantilism to the detriment of free trade. Under this system, the economic ideal of governments is to maximize exports and minimize imports to upturn national wealth. The offspring of this consummation is transnational strife further birthing constant warfare deeply rooted in economy-induced malice. The reason for this is that mercantilism encourages nations to fight over scarce resources rather than devise means of engaging in mutually beneficial trade relations. However, the latter part of the nineteenth century, when Manchester Liberalism flourished, saw the international community on the path to peace. Remarkably, this path splits into two horizontal parallels. Firstly, free trade is not bordered by forms of government, thus, nations are more peaceful and prosperous because they are not engaged in a zero-sum game. Connected to this is the reality that the expansion of free trade, as manifested at the end of Second World War, makes it costlier for each nation to go to war. Secondly, economic interdependence occasioned by free trade makes imposition of peace binding on nation states. This is made possible through prevalent economic sanctions now referred to in some scholarly quarters as economic deterrence. In a nutshell, war is a relatively rare phenomenon in the international scene. Its avoidance is traceable to a number of explanations which include military power, democracy and free trade. Much as it is admitted that military power goes a long way in chronometrically regulating war and peace; and that democracies are not only far more peaceful than other forms of government such as authoritarianism due to its nature of popular participation, but also endowed with potentials of leading to a much safer world in the long run, free trade has continued to exert itself as the least flawed and most effective mechanism for keeping the peace in the international space, unlike its other counterparts with proven potentialities of being counterproductive, and this promises to be the case for a long time to come.

\section{Acknowledgements}

I thank Professor Fujiwara (2014) for his lessons on Conditions of War and Peace offered in December, 2014, on the platform of Coursera.

\section{References}

Adedayo, A. (2011). Elections and Nigeria's National Security. In I. O. Albert et al. (Eds.), Democratic Elections and Nigeria's National Security (pp. 23-46). Ibadan: John Archers Publishers Ltd.

Akinwale, A. A. (2011). Violent Crime in Party Politics and the Electoral Process in Nigeria’s Democracy. In I. O. Albert et al. (Eds.), Democratic Elections and Nigeria’s National Security (pp. 71-85). Ibadan: John Archers Publishers Ltd.

Akinyemi, B. (1993). In Search of a New World Order. In J. Owoeye (Ed.), Understanding the New World Order (pp. 41-54). Ibadan: College Press Ltd.

Amuwo, K. (1992). International Context of Democratic Transition in Africa: Roadblocks to Democracy? In B. Carnon, Gboya, A., \& Osaghae, E. (Eds), Democratic Transition in Africa (pp. 3-7). Ibadan: Institute of African Studies.

Art, R. J. (1980). To What Ends Military Power. International Security, 4, 3-35. http://dx.doi.org/10.2307/2626666

Bank for International Settlements. www.bis.org

Bank of Russia. www.cbr.ru/eng/

Behr, H., \& Amelia, H. (2009). Misreading in International Relations Theory and Ideology Critique: Morgenthau, Waltz and Neo-Realism. Review of International Studies, 35, 327-349. http://dx.doi.org/10.1017/S0260210509008547

Blinder, A. S. (2008). Free Trade. In D. R. Henderson (Ed.), Library of Economics and Liberty: The Concise Encyclopedia of Economics (2nd Edition). Indianapolis: Liberty Funds Incorporated.

Brown, C. (2001). Understanding International Relations (2nd Edition). New York: Plagrave.

Carr, K. R., Benstein, M. H., \& Murphy, F. W. (1966). American Democracy in Theory and Practice. New York: Holt, Rinehart and Winston.

Charap, S., \& Kuchins, A. C. (2009). Economic Whiplash in Russia, an Opportunity to Bolster US-Russia Commercial Ties? Washington DC: Center for Strategic International Studies.

Danjibo, D. N. (2012). Democracy and the Minority Question in Nigeria: Evaluating Crisis Events, 1999-2007. In I. O. Albert (Ed.), A History of Social Conflict and Conflict Management in Nigeria (pp. 300-315). Ibadan: Archers Press. 
Doering, D. (2004). Countering the Myth of Manchesterism, Potsdam, Positive Liberal. In P. Altmiks (Ed.), Laissez-Faire Capitalism/Manchesterism: Truth and Myths.

www.4liberty.eu/laissez-fairecapitalism/manchesterism/

Doyle, M. W. (1983). Kant, Liberal Legacy and Foreign Affairs.

Egbuta, M. U. (2011). Understanding and Practising Democracy in Nigeria. In I. O. Albert, et al. (Eds.), Democratic Elections and Nigeria's National Security (pp. 350-365). Ibadan: John Archers Publishers Ltd.

Fujiwara, K. (2014). Lecture on Conditions of War and Peace, University of Tokyo. Coursera.

Galtung, J. (1990). Cultural Violence. Journal of Peace Research, 27, 291-305. http://dx.doi.org/10.1177/0022343390027003005

Global Trade Atlas. Global Trade Information Services 2000-2015. www.gtis.com/gta/

Graham, G. (2014). Military Power versus Economic Power in History. www.historyorb.com/world/power.php

Hitchens, C. (2002). Why Orwell Matters. New York: Basic Books.

http://www.businessdictionary.com/definition/freemarket.html

Ibeanu, O. (2012). Conceptualizing Peace. In S. G. Best (Ed.), Introduction to Peace and Conflict Studies in West Africa (pp. 3-14). Spectrum Books. Ibadan: Spectrum Books.

Igbokwe-Ibeto, C. J., \& Akhakpe, I. B. (2012). Culture, Democracy and Governance in Nigeria. In I. O. Albert (Ed.), A History of Social Conflict (pp. 236-248). Ibadan: John Archers Ltd.

Kant, I. (1795). Perpetual Peace: A Philosophical Sketch.

Katahara, E. (Ed.) (2014). East Asian Strategic Review. Tokyo: The Japan Times Ltd., The National Institute for Defence Studies, Japan.

Kerry, J. (2014). UN Secretary of State, Speech Delivered during the US-China Strategic and Economic Dialogue in Beijing, China. July 2014.

Ki-Zerbo, J. (1978). Histoire de l'Afrique Noire. Paris: Hatier.

Moravcsic, A. (1992). Liberalism and International Relations Theory. Paper No. 92-96. Cambridge, MA: Centre for European Studies, Harvard University.

Nelson, R. M. (2014). U.S.-Russian Economic Relations. CRS Insights, 7-6819. www.fas.org/sgp/crs/row/IN10119.pdf

Omobowale, A. O. (2008). Flawed Political Party Primaries in Nigeria’s Fourth Republic: The Case of the People's Democratic Party. African Journal of the Psychological Studies of Social Issues, 2, 282-291.

Onyeoziri, F. (2000). Towards a Theory of Democratic Perspective. Nigerian Political Science Association (NPSA), 2988, 309.

Russia Insider (2015). www.russia-insider.com/en/world-bank-russia-overtakes-germany-4th-economy/ri9272

Sabine, G. H., \& Thorson, T. L. (1973). A History of Political Theory. New York: Daison Press.

Slaughter, A. (1995). Liberal International Theory and International Economic Law. American University International Law Review, 10, 717-743.

Smith, A. (1776). Theory of Pacifism. London: W. Strahan and T. Cadell.

Smith, L. (2013). Adam Smith: The Father of Economics. Investopedia. www.investopedia.com/articles/economics/08/adam-smith-economics.asp

The White House, Office of the Press Secretary (2014). Statement by the President on Ukraine. www.whitehouse.gov/the-press-office/2014/07/29/statement-president-ukraine

Thorsten Nestmann (2009). US-Russia Economic Relations: Room for Improvement-But Do Not Expect Much. Deutsche Bank Research. www.dbresearch.de/PROD/DBR_MOBILE_DE-PROD/PROD0000000000243816.pdf 